19 Revue d'histoire du XIXe siècle

Société d'histoire de la révolution de 1848 et des

révolutions du XIXe siècle

$10 \mid 1994$

Le silence au XIXe siècle

\title{
Peuple, crime et secret : la mort violente dans les
} romans de Sand (1832-1853)

\section{Michèle Hecquet}

\section{OpenEdition}

\section{Journals}

Electronic version

URL: http://journals.openedition.org/rh19/76

DOI: $10.4000 /$ rh 19.76

ISSN: $1777-5329$

Publisher

La Société de 1848

\section{Printed version}

Date of publication: 1 June 1994

ISSN: 1265-1354

Electronic reference

Michèle Hecquet, « Peuple, crime et secret : la mort violente dans les romans de Sand (1832-1853) », Revue d'histoire du XIXe siècle [Online], 10 | 1994, Online since 09 September 2008, connection on 01 May 2019. URL : http://journals.openedition.org/rh19/76 ; DOI : 10.4000/rh19.76

This text was automatically generated on 1 May 2019.

Tous droits réservés 


\section{Peuple, crime et secret : la mort violente dans les romans de Sand (1832-1853)}

Michèle Hecquet

\section{ABSTRACTS}

The people, crime and secrets: violent death in the novels of George Sand (1832-2853). In the first half of the 19th century, the visibility of the people onlys seems to exists through violence and crime. Eugène Sue, Balzac, Hugo illustrate this in different ways. George Sand is attached to the crimes and secrets of the people, but she adopts the point of view either of the murderer or the friends or parents of the victims. She never writes about the penalty or the scene of the actual punishment. The collective conflicts, particularly the fatal brawls between companions, are presented and denounced in her "romans rustiques" (rustic novels). Just the same, the way she treats violence is original for three raisons: first she analyses the part of responsability of the intervention bourgeoise; she shows her hostility towards the emotional exploitation of the crime and she euphimises violent death; finally she displays unpunished murders, suggesting that all these forgotten victims have been drowned in the same silence. The heroines, like the male characters, often die for a question of honour. In the novels of George Sand public power seems non-existant, quite absent. The author of "Maîtres sonneurs" refuses to commiserate nostalgia, she prefers describing the overcharge of remorse and resentment, and the creative power of what has been forgotten.

Dans la première moitié du XIXe siècle, la visibilité du peuple semble n'exister que par le biais de la violence et du crime. Eugène Sue, Balzac, Hugo l'illustrent dans des registres différents. George Sand s'attache aux crimes et aux secrets du peuple, mais elle le fait en adoptant tantôt le regard 
des meurtriers, tantôt celui des amis ou des parents des victimes. Jamais elle n'aborde la sanction pénale ou le spectacle du châtiment. Les conflits collectifs, en particulier les rixes mortelles entre compagnons du tour de France, sont présents et dénoncés dans ses " romans rustiques". Toutefois, son traitement de la violence possède une triple originalité : elle analyse d'abord la part de responsabilité de "l'intervention bourgeoise "; elle se montre hostile à l'exploitation émotionnelle du crime et elle euphémise la mort violente ; enfin elle met en scène des assassinats impunis et suggère que toutes ces victimes oubliées sont ensevelies dans un même silence. Bien souvent les hérö̈nes comme les personnages masculins meurent pour une question d'honneur. Reste que dans les romans de George Sand, la " puissance publique " semble inexistante, presque absente. L'auteur des maîtres sonneurs refuse à la fois de s'apitoyer et de sacrifier à la nostalgie, elle préfère décrire le dépassement du remords et du ressentiment, et la puissance créatrice de l'oubli.

INDEX

Mots-clés: Violence, Silence, George Sand 